\title{
SISTEM MANAJEMEN ANTI PENYUAPAN ISO 37001 : 2016 DAN REFORMASI BIROKRASI (STUDI KASUS PADA PUSAT PELATIHAN DAN PENGEMBANGAN DAN KAJIAN DESENTRALISASI DAN OTONOMI DAERAH) Anti-Bribery Management System ISO 37001:2016 and Bureaucratic Reform (Case Study At Puslatbang Kdod)
}

\author{
Dewi Sartika ${ }^{1}$ dan Wildan Lutfi Arieyasmieta \\ ${ }^{1}$ Pusat Pelatihan dan Pengembangan dan Kajian Desentralisasi dan Otonomi Daerah \\ Jalan HM Ardans SH Ring Road 3 Samarinda, Indonesia \\ ${ }^{2}$ Pusat Pelatihan dan Pengembangan dan Kajian Desentralisasi dan Otonomi Daerah \\ Jalan HM Ardans SH Ring Road 3 Samarinda, Indonesia \\ e-mail : naurah201080@gmail.com
}

Diterima: 15 November 2019, Direvisi: 18 Februari 2020, Disetujui: 26 November 2020

\begin{abstract}
Abstrak
Birokrasi bebas dan bersih melayani merupakan tujuan pelaksanaan reformasi birokrasi yang dicanangkan sejak tahun 2009. Percepatan reformasi birokrasi dalam roda pemerintahan dengan membangun Zona Integritas (ZI) sebagai kunci penting dalam pencegahan korupsi di pemerintahan, salah satunya adalah kewajiban memiliki standar pelayanan yang terstandardisasi internasional yang dapat ditandai dari prosedur pelayanan yang ditetapkan tidak membuka celah dan potensi korupsi, kolusi dan nepotisme (KKN). ISO 37001 merupakan bentuk implementasi pengendalian gratifikasi. Penelitian ini bertujuan menganalisis sejauh mana penerapan ISO 37001 dalam tubuh organisasi. Studi kasus dilakukan pada Pusat Pelatihan dan Pengembangan dan Kajian Desentralisasi dan Otonomi Daerah dengan metode survei dan review literature, wawancara kepada 7 (tujuh) responden dan analisis dokumen yang menunjukkan bahwa organisasi sudah cukup optimal dalam penerapan ISO 37001. Dampak penelitian ini adalah sebagai pilot project penerapan sistem manajemen anti penyuapan sehingga membantu organisasi mencegah dan meminimalisir terjadinya kasus gratifikasi, korupsi, kolusi dan nepotisme (KKN) yang melibatkan oknum perorangan atau yang terorganisir dilakukan oleh korporasi.
\end{abstract}

Kata kunci: Sistem Manajemen Anti Penyuapan, ISO 37001 : 2016, reformasi birokrasi, korupsi, kolusi dan nepotisme

\begin{abstract}
Free and clean bureaucracy are the goals of implementing bureaucratic reform that was launched since 2009. The acceleration of bureaucratic reform in the wheels of government is done among others by building an Integrity Zone as an important key in preventing corruption in government. One is the obligation to have international standardized service standards that can be marked from the established service procedures that do not open the gaps and potential for corruption of collution and nepotism. ISO 370001 is a form of implementing gratification control. This study aims to analyze the extent of the application of ISO 37001 in the body of the organization. The case study was carried out on Training and Development and Study Center for Decentralization and Regional Autonomy with survey and a literature review method, interview with 7 respondent and document analysis that showed that the organization had implemented the optimal application of ISO 37001. The impact of this research was as a pilot project for implementing an anti-bribery management system so that it helped organizations prevent and minimize the occurrence of gratification cases, corruption of collution and nepotism involving individual or organized person carried out by the corporation
\end{abstract}

Keyword: Anti-Bribery Management System, ISO 37001:2016, bureaucratic reform, corruption, collution and nepotism

\section{PENDAHULUAN}

The Global Competitiveness Report 2013-2014 mencatat peringkat Indonesia meningkat dari ranking 55 (tahun 2008-2009) menjadi 38 (2013-2014), yang ditandai kinerja birokrasi membaik akan tetapi korupsi memburuk. Indeks korupsi menjadi 19.3 sebelumnya 10.3 Sedangkan PERC (Political and Economical Risk Consultancy) juga merilis Indonesia berada di ranking 8.37 dalam peringkat $1-10$ (terbaik hingga terburuk) dalam indeks efisiensi birokrasi di Indonesia (PERC Ltd, Jan 2012). Transparency International mencatat indeks korupsi Indonesia berada di peringkat 118 dengan indeks 32 (dari skor $0-100$ korupsi tertinggi hingga ke skor sangat bersih)(Indonesia \& Nasional, 2016).

Indonesia bersih melayani dan bebas korupsi adalah cita-cita besar tata kelola pemerintah yang baik melalu terbitnya Peraturan Presiden (Perpres) Nomor 81 Tahun 2010 tentang Grand Design Reformasi 
Birokrasi 2010-2025 dengan tiga sasaran hasil utama yaitu peningkatan kapasitas dan akuntabilitas kinerja birokrasi, pemerintahan yang bersih dan bebas KKN, serta peningkatan kualitas pelayanan publik kepada masyarakat.

$$
\text { Percepatan reformasi birokrasi }
$$

pemerintahan dilakukan diantaranya dengan membangun Zona Integritas (ZI) Wilayah Bebas dari Korupsi (WBK) dan Wilayah Birokrasi Bersih dan Melayani (WBBM) yang tertuang dalam Peraturan Menteri Pendayagunaan Aparatur Negara - Reformasi Birokrasi Nomor 10 Tahun 2019 tentang Pedoman Pembangunan Zona Integritas Menuju Wilayah Bebas Dari Korupsi dan Wilayah Birokrasi Bersih dan Melayani di Lingkungan Instansi Pemerintah. Peraturan tersebut sebagai acuan bagi pejabat di lingkungan Kementerian/Lembaga dan Pemerintah Daerah (K/L/Pemda) dalam rangka Pembangunan Zona Integritas Menuju Wilayah Bebas dari Korupsi dan Wilayah Birokrasi Bersih dan Melayani melalui pelaksanaan kegiatan-kegiatan dalam bentuk yang lebih nyata secara terpadu dan disesuaikan dengan kebutuhan Kementerian/Lembaga/Pemerintah daerah yang bersangkutan.

Sesuai Instruksi Presiden Nomor 10 Tahun 2016 tentang Aksi Pencegahan dan Pemberantasan Korupsi, Badan Standardisasi Nasional (BSN) telah menetapkan SNI ISO 37001 Sistem Manajemen Anti Penyuapan (SMAP) untuk membantu organisasi mengendalikan praktik penyuapan dengan cara mencegah, mendeteksi, melaporkan dan menangani penyuapan. (Lukiawan, 2019) dalam penelitian dengan judul Kesiapan Organisasi Dalam Implementasi Standar ISO 37001 (Studi Kasus di UD. X dan Dinas Y) merupakan penelitian studi kasus dengan menggunakan metode analisis gap untuk mengetahui tingkat kesiapan implementasi standar yang dilakukan organisasi. Penelitian ini mencoba memberikan gambaran mengenai tingkat kesiapan suatu organisasi terhadap implementasi standar terkait anti bribery management system dengan membandingkan dua organisasi di kota Yogyakarta dan kota Palembang. Penelitian ini mengulas kesiapan organisasi ditinjau dari aspek kelembagaan organisasi, kepemimpinan, perencanaan, dan dukungan, tinjauan manajemen. Hasil penelitian menunjukkan pelaksanaan yang berada pada level siap dengan tingkat kepentingan terkait implementasi anti bribery management system pada level penting dan nilai gap implementasi yang sangat kecil. Ini menggambarkan bahwa UD. $X$ telah mampu memahami dan menerapkan sistem manajemen anti penyuapan dalam kegiatan bisnis meskipun pada tahap awal, upaya peningkatan perbaikan tetap dilakukan agar secara sistem dapat berjalan optimal. Sedangkan pada Dinas $Y$ ditemukan bahwa efektifitas pelaksanaan berada pada level awal (preliminary) dengan tingkat kepentingan yang dianggap penting, ditambah lagi dengan gap implementasi yang cenderung kecil. Dinas $Y$ dianggap perlu mengupayakan perbaikan dan peningkatan pemahaman secara menyeluruh meliputi tujuh aspek SNI ISO 37001 mengingat core business yang ditujukan kepada publik di bidang kesehatan. Penelitian ini dapat disampaikan bahwa organisasi perlu mengantisipasi fenomena praktik korupsi. Kedua organisasi ini telah siap untuk menerapkan ISO 37001:2016 - Antibribery management systems - Requirements with guidance for use untuk membantu organisasi memerangi suap. Riset ini berusaha menggali sejauh mana penerapan Sistem Manajemen Anti Penyuapan (SMAP) ISO 37001:2016 ini diterapkan pada Pusat Pelatihan dan Pengembangan dan Kajian Desentralisasi dan Otonomi Daerah (Puslatbang KDOD) dan untuk mengetahui faktor apa saja yang mempengaruhi penerapan ISO 37001 dalam tubuh organisasi yang diteliti.

\section{TINJAUAN PUSTAKA}

\subsection{Suap dan Kebijakan Anti Penyuapan}

Penelitian sejenis (Boly \& Gillanders, 2018) menggambarkan kebijakan anti korupsi sebagai pertahanan kekuasaan yang diskresioner dan kualitas kelembagaan. Penelitian ini menganalisis insentif pembuat kebijakan untuk memerangi korupsi di bawah kualitas kelembagaan yang berbeda. Tulisan ini mencoba mengurai keberadaan pejabat publik yang tidak melakukan korupsi namun secara signifikan mendistorsi lembaga anti korupsi dengan memilih kemungkinan deteksi yang lebih rendah terkait dengan tindakan pejabat publik itu sendiri. Kesimpulan yang dapat diambil dari penelitian ini adalah kesetaraan di depan hukum adalah prinsip bahwa setiap orang harus diperlakukan sama di hadapan hukum, sementara manipulabilitas merujuk pada sejauh mana lembaga dapat dimanipulasi oleh para pembuat keputusan. Besaran distorsi sekitar $70 \%$ untuk kemungkinan deteksi rendah pada pembuat kebijakan. Kondisi ini juga terjadi pada pembuat kebijakan yang jujur dengan memberlakukan tingkat deteksi yang kurang ketat ketika secara resmi menerapkan tindakan 
mereka sendiri. Penggelapan dan mekanisme antikorupsi yang lebih lemah semakin bertentangan dengan kebaikan publik dan ini dapat menjadikan tindak korupsi lebih lanjut. Pemahaman tentang insentif pembuat kebijakan dan kemauan untuk membiarkan mereka berenang melalui jaring mereka sendiri (bahkan sementara) dapat berfungsi untuk memperkuat undang-undang anti-korupsi, yang mungkin mengarah pada tingkat korupsi yang lebih rendah di masyarakat. Dalam hal ini, jalan yang menarik dan berpotensi penting untuk penelitian lebih lanjut dapat dibangun di atas kerangka kerja kami dan menyelidiki apakah aturan 'memilih keluar' khusus bagi pembuat kebijakan memiliki kekuatan untuk mengarah pada upaya anti-korupsi yang lebih kuat.

Sihombing (2018) mengurai persepsi kaum muda terhadap korupsi dan integritas. Riset menunjukkan bahwa mereka memahami korupsi tetapi kurang familiar dengan integritas sehingga perlu integrasi dengan kurikulum pendidikan karena mereka gen perubahan dalam memerangi korupsi dan upaya mendukung pemerintah dan aktivitas kepemudaan dalam mengurangi korupsi.

Tipe penyuapan (Indonesia \& Nasional, 2016) seperti penyuapan di sektor publik, swasta dan nirlaba; penyuapan oleh organisasi; penyuapan oleh personel yang bertindak atas nama organisasi atau untuk kepentingannya; penyuapan oleh rekan bisnis dari sebuah organisasi yang bertindak atas nama nama organisasi atau untuk kepentingannya; penyuapan oleh personel organisasi sehubungan dengan aktivitas organisasi; penyuapan rekan bisnis organisasi sehubungan dengan aktivitas organisasi, dan penyuapan langsung dan tidak langsung (misalnya menawarkan atau menerima suap melalui atau oleh pihak ketiga).

Wesley Cragg dalam working paper (Cragg, 2016)mencoba menggambarkan suap, korupsi dan norma moral dalam konteks etika bisnis. Pembahasan suap telah berkembang dan menjadi menarik perhatian dalam dunia usaha, pemerintah dan penetapan standar asosiasi dan lembaga bisnis internasional. Karakteristik penyuapan sebagai tindakan tidak etis dijelaskan bahwa suap membutuhkan penipuan yang disengaja; suap menghasilkan ketidakadilan dan ketidakadilan; suap merusak karakter moral; suap bersifat menular; suap merusak reputasi; suap kontradiktif dengan nilai-nilai pasar yang bebas dan kompetitif; suap merusak pembangunan ekonomi dan sektor publik dan swasta; dan suap sebagai rasionalisasi kegagalan.

Alexander Pavroz (Pavroz, 2017), menjelaskan bahwa sebagaimana negara besar seperti Rusia dengan paradoks tingkat korupsi yang tinggi membuat serangkaian model pemerintahan yang korup sebagai bentuk langkah antisipasi atas tindakan suap. Tingkat korupsi yang relatif kuat saat ini justru membuat pemerintah memaksa untuk membuat institusi baru dalam membasmi suap, sogokan, kontrak sepihak dan sejenisnya. Kondisi ini merusak institusi negara dan justru malah melemahkan pemerintah itu sendiri. Keadaan ini membawa pada kesimpulan bahwa langkah anti-korupsi yang efektif di Rusia hanya dapat dilakukan jika ada perubahan rezim dan realisasi konsekuensi dari reformasi demokrasi, pasar dan administrasi.

2016) Corina Joseph (Joseph Joseph et al.,
dalam studinya mencoba membandingkan pengungkapan kode etik anti korupsi dan whistle-blowing di Malaysia dan Indonesia. Hasil perbandingan studi, ada pengungkapan praktik anti-korupsi yang lebih tinggi di antara perusahaan Indonesia dibandingkan dengan yang dari Malaysia. Studi ini menjelaskan bahwa pengungkapan praktik anti korupsi ditujukan untuk memerangi suap, hubungan bisnis yang bertanggungjawab, verifikasi, jaminan eksternal, kode etik dan whistle-blowing.

Nur Shafiqa Kapeli (Kapeli \& Mohamed, 2015) mendefinisikan gratifikasi adalah tindakan memberi atau menerima gratifikasi atau hadiah dalam bentuk uang tunai melakukan tugas sehubungan dengan uraian tugasnya. Korupsi tidak hanya berupa uang tetapi juga bisa juga dalam bentuk hadiah dalam bentuk barang, penawaran diskon, suara, layanan (termasuk jenis kelamin), posisi kerja atau penempatan, pinjaman dan segala bentuk pembayaran dan pembelian.

\subsection{Manajemen Perubahan dan Reformasi Birokrasi}

Percepatan reformasi birokrasi pada unit kerja dilakukan diantaranya dengan membangun Zona Integritas (ZI) Wilayah Bebas dari Korupsi (WBK) dan Wilayah Birokrasi Bersih dan Melayani (WBBM) yang tertuang dalam Peraturan Menteri Pendayagunaan Aparatur Negara - Reformasi Birokrasi Nomor 10 Tahun 2019 tentang Pedoman Pembangunan Zona Integritas Menuju Wilayah Bebas Dari Korupsi 
dan Wilayah Birokrasi Bersih dan Melayani di Lingkungan Instansi Pemerintah.

Delapan area perubahan dalam reformasi birokrasi adalah pertama,organisasi yang tepat fungsi dan tepat ukuran; kedua, tata laksana, yaitu sistem, proses dan prosedur kerja yang jelas, efektif, efisien, terukur dan sesuai prinsip good governance; ketiga, peraturan perundang-undangan, regulasi yang lebih tertib, tidak tumpang tindih dan kondusif, keempat, sumber daya aparatur, SDM aparatur yang berintegritas, netral, kompeten, kapabel, profesional, berkinerja tinggi dan sejahtera; kelima, pengawasan, meningkatnya penyelenggaraan pemerintahan yang bebas KKN, keenam, akuntabilitas, meningkatnya kapasitas dan kapabilitas kinerja birokrasi, ketujuh, pelayanan publik, pelayanan prima sesuai kebutuhuan dan harapan masyarakat, kedelapan, mindset dan cultural set aparatur, birokrasi dengan integritas dan kinerja yang tinggi.

Anggraeni (2014) berpendapat bahwa untuk menciptakan perubahan dalam sistem pelayanan yang baik adalah dengan reformasi birokrasi dan pemberantasan korupsi. Tindakan korupsi sangat rentan terjadi dikarenakan rendahnya komitmen pemerintah dalam kualitas penyelenggaraan pelayanan publik. Mental korupsi yang masih menjadi kendala dan menghambat proses reformasi birokrasi. Kondisi ini diperparah dengan potret buruknya pelayanan publik sehingga mengarah pada perbuatan tindak pidana korupsi. Stigma negatif di masyarakat mengenai pelayanan publik semakin memberikan gambaran bahwa anggapan pelayanan publik yang rumit, lama dan membutuhkan biaya. Kondisi ini dijawab dengan pemerintahan era saat ini dengan menyatakan perang terhadap citra buruk atas pelayanan publik. Langkah yang diambil adalah dengan memasukkan metode revolusi mental kedalam program dan kebijakan. Sebagai tindakan nyata memerangi korupsi adalah dengan mengatur sistem lelang jabatan, memperbaiki kecepatan dalam sistem pelayanan publik secara elektronik sekaligus menjadi momentum internalisasi revolusi mental kedalam sistem reformasi birokrasi.

Hongxia Zang (Zhang et al., 2019) menganalisis mengenai upaya anti korupsi didasarkan dari analisis empiris 12 provinsi di Cina menyimpulkan bahwa persepsi publik tentang korupsi memengaruhi sikap terhadap kredibilitas pemerintah, upaya anti-korupsi mengurangi kerusakan pada kepercayaan publik terhadap pemerintah pusat tetapi tidak secara signifikan mengurangi kerusakan pada kepercayaan terhadap pemerintah provinsi, dan upaya gagal anti-korupsi. Memperbaiki kepercayaan politik secara efektif. Berdasarkan hasil, tiga implikasi kebijakan muncul: (1) upaya anti-korupsi harus lebih ditingkatkan sebagai metode penting untuk menjaga kesehatan partai yang berkuasa dan sebagai metode untuk memenangkan dukungan publik, (2) pemerintah harus meningkatkan upaya diversifikasi dalam memberantas korupsi, berinovasi mekanisme anti-korupsi, dan memperluas partisipasi publik dalam upaya anti-korupsi, dan (3) upaya anti korupsi harus diperkuat dengan menjadikan antikorupsi sebagai tujuan penting dari regulasi.

Zulfia et.al (Hanum \& Syahr, 2019) dalam penelitiannya mengevaluasi penerapan standar akreditasi penjaminan mutu pengadilan menyimpulkan bahwa hasil evaluasi matriks Importance Performance Analysis menunjukkan indikator dari masing-masing kriteria akreditasi penjaminan mutu masih banyak yang perlu ditinjau kembali oleh stakeholder untuk dapat dilakukan perbaikan dan peningkatan pada beberapa kriteria akreditasi yang menjadi prioritas masyarakat. Kriteria akreditasi yang telah memenuhi harapan masyarakat adalah fokus pelanggan dan manajemen sumber daya. Kriteria akreditasi yang belum memenuhi harapan masyarakat adalah manajemen proses.

\subsection{Sistem Manajemen Anti Penyuapan (SMAP)}

Sesuai Instruksi Presiden Nomor 10 Tahun 2016 tentang Aksi Pencegahan dan Pemberantasan Korupsi, Badan Standardisasi Nasional telah menetapkan SNI ISO 37001 Sistem Manajemen Anti Penyuapan (SMAP) untuk membantu organisasi mengendalikan praktik penyuapan dengan cara mencegah, mendeteksi, melaporkan dan menangani penyuapan. Ini bermanfaat sebagai panduan dalam menerapkan sistem Manajemen Anti penyuapan, sebagai jaminan organisasi telah menerapkan pencegahan penyuapan, dan sebagai bukti dalam hal penyelidikan bahwa organisasi telah mengambil langkah untuk mencegah penyuapan. Keberadaan ISO 37001 tidak untuk menjamin bahwa di suatu organisaSi tidak akan ada suap, namun kepatuhan terhadap standar ini menjadi bukti praktik pencegahan penyuapan di tubuh organisasi.

ISO 37001:2016 adalah sistem manajemen anti suap uang dirancang untuk membantu organisasi menetapkan, menerapkan, memelihara dan meningkatkan 
program kepatuhan anti-suap (WQA, 2019). (Kafel, 2016) menggambarkan bahwa suap adalah salah satu masalah yang berpengaruh kualitas hidup. Sebagaimana tulisan ini menjelaskan manajemen anti penyuapan dengan menggunakan spesifikasi antipenyuapan Polandia dan standar ISO/DIS 37001. Sampai saat ini sistem manajemen mutu (ISO 9001) adalah sistem manajemen yang paling populer diimplementasikan dalam organisasi, namun seiring dengan konteks penyuapan, tahun 2013 dikembangkan ISO 37001 mengenai anti-bribery management system. Sistem ini bertujuan mencegah penyuapan dan mempromosikan bisnis yang berbudaya etis baik untuk organisasi dengan lingkup yang besar, menengah, kecil dari sektor publik dan swasta. Antibribery management system diharapkan dapat mendukung organisasi menjadi lebih efektif dengan keterlibatan top management. Sistem ini akan efektif merubah pola pikir dan budaya korupsi secara keseluruhan organisasi. Sistem ini juga terkait dengan level korupsi di Polandia, seperti pejabat pemerintah, organisasi dan warga negara yang menerima dan menuntut suap.

Enam prinsip SNI ISO 37001:2016 yaitu pertama, prosedur yang proporsional. Kebijakan dan prosedur yang ada harus proporsional dengan Risiko Penyuapan yang dihadapi. Kedua, komitmen pemimpin. Kepemimpinan yang efektif pada pencegahan penyuapan disesuaikan dengan ukuran organisasi, struktur manajemen dan keadaan saat itu. Pundak pemimpin dibebani amanat menjaga kebijakan agar dilaksanakan, dikomunikasikan kepada pemangku kepentingan dan menjamin hasil analisis resiko. Ketiga, Manajemen Risiko. Terkait isu internal dan eksternal dan pemangku kepentingan, analisis resiko dilakukan dan didokumentasikan. Secara eksternal, isu terbagi menjadi resiko negara, resiko sektor, resiko transaksi, resiko dari peluang bisnis dan resiko rekanan. Kompleksitas metode yang diambil mencerminkan maturitas organisasi. Keempat, Due diligence/ uji kepatutan. Prosedur kegiatan yang dilakukan terhadap proses/personil/unit kerja yang beresiko diatas rendah untuk memastikan tidak terjadi baik. Kaji due diligence terhadap pemangku kepentingan perlu mengkaji kebenaran lokasi, kepatuhannya terhadap aturan hukum dan kebijakan anti korupsi yang dimiliki. Kelima, komunikasi yang efektif. Sosialisasi dan diseminasi aturan standar sesuai peruntukan harus dilakukan dengan membuat daftar komunikasi dan penanggungjawab ke internal organisasi (training/sosialisasi) mengenai kebijakan anti-suap dan dokumentasi kepada internal dan eksternal. Keenam, Monitoring dan evaluasi. Tim Kepatuhan dibentuk untuk melaporkan monitoring kepada pimpinan puncak secara berkala berupa perubahan risiko, prosedur maupun kebijakan yang menunjang efektifitas penerapan sistem manajemen anti korupsi.

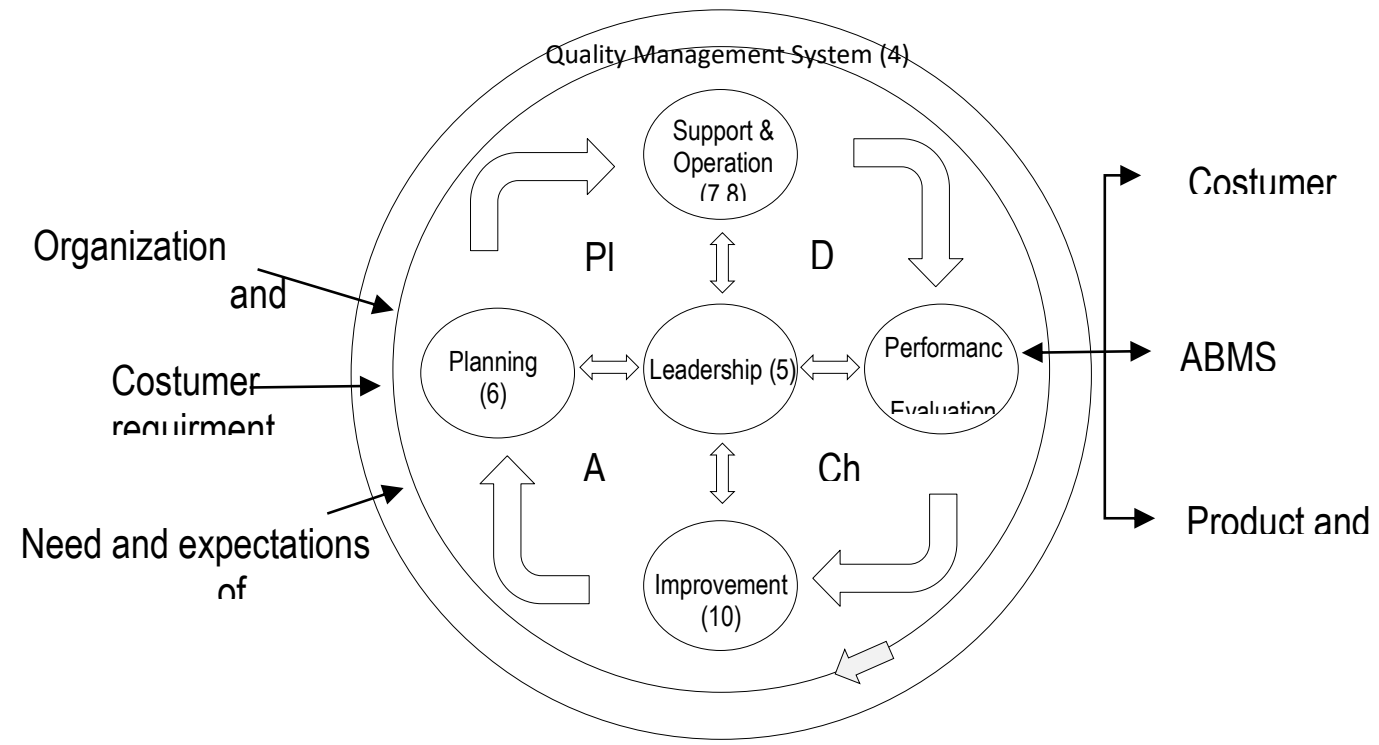

Gambar 1 Skema Hubungan Klausul.

Sumber : BSN, 2019. 
Skema hubungan klausul mendeskripsikan konteks aktivitas yang terorganisir. Kualitas aktivitas yang dimaksud menjadi lebih baik dan sesuai dengan yang diharapkan. Dalam bingkai Quality Manajement System dikenal dengan sistem PDCA (Plan, Do, Check dan Act). Konteks organisasi secara umum disertai dengan kebutuhan pelanggan dan ekspektasi dan relevansi dari pihak yang berkepentingan merupakan awal dari hubungan klausul. Secara umum kepemimpinan merupakan hal utama dalam lingkaran Quality Management System. Plan dikenal dengan perencanaan yang menghubungkan antara perencanaan dan dukungan operasional dalam suatu organisasi. Do adalah proses pelaksanaan yang didasarkan dari perencanaan yang dioperasionalkan dengan melakukan evaluasi kinerja secara berkala. Check lebih kepada memeriksa hasil evaluasi kinerja dan memastikan bahwa proses pelaksanaan telah dilakukan sesuai dengan yang diharapkan. Act merupakan tindakan dalam hal ini lebih kepada perbaikan pelaksanaan dari suatu produk yang dihasilkan. Quality Management System juga memberikan dampak pada kepuasan pelanggan, produk dan layanan yang ada di dalam suatu organisasi. Peningkatan Quality Manajement System juga akan meningkatkan kepuasan pelanggan yang disertai dengan kualitas produk dan layanan.

Liu dalam (Lombardi, Trequattrini, Cuozzo, \& Cano-Rubio, 2019) memberikan penjelasan bahwa pengungkapan anti korupsi diarahkan untuk meningkatkan akuntabilitas dewan perusahaan terhadap pemangku kepentingan. Jadi, adopsi beberapa pedoman internasional (misal., GRI G3, Transparency International, UN Global Ringkas, standar AA1000, Foretica SGE21, Etos CSR, ISO 26000: 2010; ISO 37001: 2016) dapat menjadi tambahan untuk promosi tindakan untuk mencegah korupsi di tingkat organisasi.

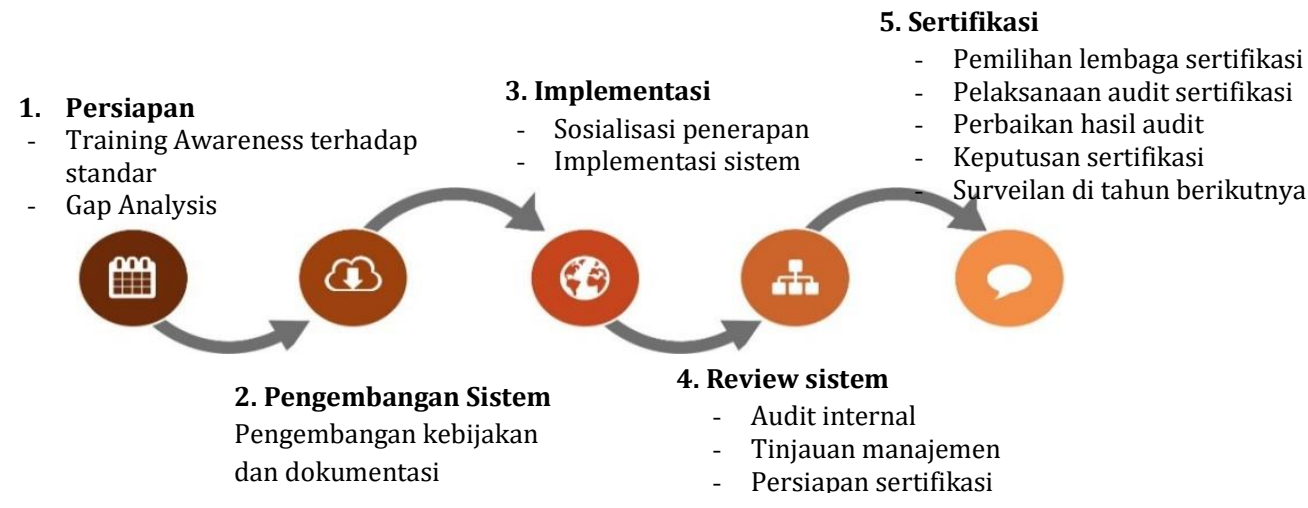

Gambar 2 Tahapan Penerapan SNI ISO 370001 : 2016. Sumber : BSN, 2019

Penerapan SNI ISO 37001:2016 mempunyai 5 (lima) tahapan yang harus dilakukan untuk dapat memenuhi unsur yang diharapkan dari ISO 37001:2016. Pertama adalah persiapan dengan memberikan pelatihan mengenai kesadaran akan pentingnya standar dalam suatu organisasi. Kondisi ini juga di sejalan dengan analisis kesenjangan standar yang ada di organisasi. Tahapan kedua lebih kepada bagaimana kebijakan organsiasi dapat dikembangkan sesuai dengan kebutuhan dan terdokumentasikan dengan baik. Tahapan selanjutnya adalah implementasi dari pengembangan kebijakan yang sudah dikembangkan dengan membuat sosialisasi penerapan dan implementasi sistem. Pada tahap ini semua proses pelaksanaan sebagai produk organisasi diharapkan sudah sesuai dengan standar yang telah disusun dan dikembangkan secara kebijakan. Kemudian dilanjutkan pada tahapan ke empat dengan fokus pada review sistem dalam konteks audit internal, tinjauan manajemen atas proses penyelenggaraan organsiasi. Pada tahapan ini dilakukan untuk memastikan bahwa organisasi telah komitmen untuk ke tahapan sertifikasi. Pada tahapan sertifikasi sangat perting untuk memilih lembaga sertifikasi. Pada tahapan ini akan dilakukan audit sertifikasi yang nantinya dari hasil audit akan dilakukan perbaikan hasil audit oleh organsiasi yang akan disertifikasi. Setelahnya akan dikeluarkan keputusan sertifikasi. Nantinya untuk memastikan bahwa 
ISO 37001:2016 telah berjalan sesuai dengan standar, maka akan dilakukan surveilan di tahun berikutnya secara berkala.

Terdapat beberapa klausul pada ISO 37001:2016, pertama, pada konteks organisasi yang akan menentukan relevansi isu baik di internal maupun eksternal dengan maksud untuk pencapaian tujuan dan hasil yang diinginkan dari sistem manajemen anti penyuapan. Kedua, adalah kepemimpinan yang mampu memberikan arahan dan menjaga komitmen terhadap sistem manajemen anti penyuapan baik dalam konteks kebijakan dan implementasi. Ketiga, adalah perencanaan sistem manajemen anti penyuapan yang dirancang untuk memastikan, mencegahatau mengurangi tindakan yang tidak diinginkan dan relevan dengan kebijakan anti penyuapan. Keempat, adalah dukungan terkait sumber daya yang ada diorganisasi dalam menetapkan, menerapkan, pemeliharaan dan peningkatan berkelanjutan sehingga sistem manajemen anti penyuapan dapat diimplementasikan dengan baik. Kelima, adalah operasi yang dalam hal ini terkait dengan perencaan dan pengendalian operasi. Pada klausul ini, organisasi harus mampu merencanakan, menerapkan, meninjau dan mengendalikan proses pelaksanaan organisasi dalam menjamin penyelenggaraan anti penyuapan yang ada diorganisasi. Keenam, adalah evaluasi kinerja yang ditujukan untuk memantau, mengukur, menganalisis dan evaluasi dari penyelenggaraan sistem manejemen anti penyuapan yang ada di organisasi dapat dilakukan dengan audit internal hingga tinjauan manajemen dari yang paling bawah hingga manajemen puncak. Tahapan ketujuh, adalah peningkatan berkelanjutan yang harus dilakukan oleh organisasi secara terus menerus. Hal ini harus dilakukan sehingga menejemen anti penyuapan menjadi lebih efektif dan dapat memenuhi kebutuhan dan komitmen anti penyuapan yang ada di organisasi. Secara umum dari keseluruhan klausul harus dipenuhi untuk menjaga komitmen organisasi dalam menerapkan anti penyuapan.

\section{METODE PENELITIAN}

Penelitian ini merupakan riset deskriptifkuantitatif dengan mengambil metode studi kasus. Definisi studi kasus dari literatur adalah suatu serangkaian kegiatan ilmiah yang dilakukan secara intensif, terinci dan mendalam tentang suatu program, peristiwa, dan aktivitas, baik pada tingkat perorangan, sekelompok orang, lembaga, atau organisasi untuk memperoleh pengetahuan mendalam tentang peristiwa tersebut. Peristiwa yang dipilih selanjutnya disebut kasus adalah hal yang aktual (real-life events), yang sedang berlangsung, bukan sesuatu yang sudah lewat (Prof. Dr. H. Mudjia Rahardjo, 2017). Teknik pengumpulan data melalui review literatur/studi kepustakaan, wawancara dengan responden yang terlibat dalam pengambilan kebijakan organisasi, dokumentasi, observasi langsung ke lokasi penelitian.

Puslatbang KDOD merupakan obyek penelitian yang mewakili organisasi pemerintahan yaitu Lembaga Administrasi Negara- Republik Indonesia. Pemilihan objek penelitian adalah dikarenakan unit analisis sudah mendapatkan sertifikat ISO 37001:2016 dan bimbingan penerapan SNI 37001 serta merupakan salah satu pilot project yang menerapkan zona Integritas (ZI) menuju Wilayah bebas Korupsi (WBK)/Wilayah bebas dan bersih melayani (WBBM). Pengumpulan data primer dilakukan dengan survei dan wawancara dengan 7 (tujuh) responden perwakilan manajemen. Dimensi pertanyaan diambil dari kriteria/persyaratan klausul dalam ISO 37001. Aspek-aspek yang dinilai dalam implementasi adalah Kelembagaan Organisasi, Kepemimpinan, Perencanaan, Dukungan, Operasi, Evaluasi Kinerja, dan Peningkatan.

Tabel 1 Level kesiapan penerapan sistem manajemen anti penyuapan (SMAP).

\begin{tabular}{cccl}
\hline Level & Nama & & \\
& Level & & Karakteristik \\
\hline 1 & Not ready & $\checkmark$ & Belum adanya adanya pemahaman mengenai SMAP \\
& & $\checkmark$ & Belum adanya pemahaman mengenai visi, misi dari SMAP \\
& & $\checkmark$ & Tidak menggambarkan fenomena atau permasalahan MAP \\
2 & Preliminary & $\checkmark$ & Sudah mengenal pentingnya kegiatan MAP \\
& & $\checkmark$ & Proses dalam organisasi sudah menggambarkan kegiatan MAP \\
& & $\checkmark$ & Sudah terdapat individu yang menggalakkan SMAP
\end{tabular}




\begin{tabular}{cccc}
\hline Level & $\begin{array}{c}\text { Nama } \\
\text { Level }\end{array}$ & & Karakteristik \\
\hline 3 & Ready & $\checkmark$ & Individu dalam organisasi sudah mempraktikkan aktivitas yang efektif \\
& & & untuk mendukung MAP \\
& & $\checkmark$ & Kegiatan MAP sudah dilaksanakan setiap waktu di setiap kegiatan \\
& & & pekerjaan \\
& & $\checkmark$ & Kegiatan MAP sudah ditemukan pada setiap individu \\
4 & & $\checkmark$ & Sudah ada sistem dokumentasi \\
& Receptive & $\checkmark$ & MAP sudah berjalan efisien dan efektif \\
& & $\checkmark$ & Sudah ada suatu standar atau aturan yang dipatuhi \\
5 & Optimal & $\checkmark$ & Organisasi telah memiliki kemampuan untuk beradaptasi dan fleksibel \\
& & terhadap persyaratan yang ditentukan dalam SMAP \\
\hline
\end{tabular}

Sumber Rao (2005) dalam (Lukiawan, 2019)

Metode analisis yang digunakan adalah metode analisis gap atau ImportancePerformance Analysis (IPA). Analysis gap adalah metode untuk mengetahui kesenjangan antara kondisi ideal yang ingin dicapai (tingkat kepentingan) dengan kondisi riil saat survei (tingkat efektifitas pelaksanaan). Parameternya menggunakan skala likert, dimana semakin kecil nilai gap maka semakin baik kondisi organisasi dalam penerapan sistem manajemen anti penyuapan. Ini tergambarkan dalam grafik, dari nilai tengah faktor kesiapan diperoleh dengan penilaian individu memiliki kewenangan dalam pengambilan keputusan di organisasi. Rentang jawaban diperoleh dari rata-rata persepsi efektifitas kondisi penerapan SMAP, sesuai tabel kesiapan diatas.

\section{HASIL DAN PEMBAHASAN}

\subsection{Implementasi SMAP}

\subsubsection{Aspek Kelembagaan Organisasi}

Hasil penilaian tingkat implementasi pada aspek kelembagaan Organisasi dimana terdapat 2 (dua) item pertanyaan, secara keseluruhan kondisi implementasi standar SMAP pada organisasi memiliki nilai rerata sebesar 4,50. Sedangkan pada tingkat kepentingan memiliki nilai rerata 4,92 yang berarti implementasi standar ini dianggap sangat penting.Ini juga ditandai dari tingkat kesenjangan yang rendah yaitu sebesar 0,42.

\subsubsection{Aspek Kepemimpinan}

Hasil penilaian tingkat implementasi pada aspek Kepemimpinan dimana terdapat 3 (tiga) item pertanyaan, secara keseluruhan kondisi implementasi standari SMAP pada organisasi memiliki nilai rerata sangat baik sebesar 4,61. Sedangkan pada tingkat kepentingan rerata 4,78 yang berarti implementasi standar ini dianggap sangat penting. Tingkat kesenjangan sebesar 0,17 .

\subsubsection{Aspek Perencanaan}

Hasil penilaian tingkat implementasi pada aspek Perencanaan dimana terdapat 1 (satu) item pertanyaan, secara keseluruhan kondisi implementasi standari SMAP pada organisasi memiliki nilai rerata sebesar 4,50 (sangat baik). Sedangkan pada tingkat kepentingan memiliki nilai rerata 4,67 yang berarti implementasi standar ini dianggap sangat penting. Ini juga ditunjukkan oleh tingkat gap yang rendah sebesar 0,17 .

\subsubsection{Aspek Dukungan}

Hasil penilaian tingkat implementasi pada aspek Dukungan dimana terdapat 4 item pertanyaan, secara keseluruhan kondisi implementasi standari SMAP pada organisasi memiliki nilai rerata baik sebesar 3,83 . Sedangkan pada tingkat kepentingan memiliki nilai rerata 4,50 yang berarti implementasi standar ini dianggap sangat penting. Hal yang sama ditunjukkan dari tingkat kesenjangan yang rendah yaitu sebesar 0,67.

\subsubsection{Aspek Operasi}

Hasil penilaian tingkat implementasi pada aspek Operasi dimana terdapat 2 (dua) item pertanyaan, secara keseluruhan kondisi implementasi standari SMAP pada organisasi memiliki nilai rerata sebesar baik yaitu sebesar 3,67 . Sedangkan pada tingkat kepentingan memiliki nilai rerata 4,42 yang berarti implementasi standar ini dianggap sangat penting. Tingkat gap yang dimiliki rendah yaitu sebesar 0,75.

\subsubsection{AspekTinjauan Manajemen}

Hasil penilaian tingkat implementasi pada aspek Tinjauan Manajemen dimana terdapat 43 (tiga) item pertanyaan, secara keseluruhan kondisi implementasi standari SMAP pada organisasi memiliki nilai rerata sebesar baik sebesar 3,72. Sedangkan pada tingkat kepentingan memiliki nilai rerata 4,67 yang berarti implementasi standar ini dianggap 
sangat penting. Ini juga ditunjukkan dari tingkat kesenjangan agak rendah sebesar 0,94.

\subsubsection{Aspek Peningkatan}

Hasil penilaian tingkat implementasi pada aspek Peningkatan dimana terdapat 2 (dua) item pertanyaan, secara keseluruhan kondisi implementasi standari SMAP pada organisasi memiliki nilai rerata sangat baik sebesar 3,67. Sedangkan pada tingkat kepentingan memiliki nilai rerata 4,67 yang berarti implementasi standar ini dianggap sangat penting. Dengan tingkat gap rendah yaitu sebesar 0,83.

Grafik/diagram dibawah tergambarkan bahwa nilai dari setiap aspek standar dalam SNI ISO 37001 diperoleh hasil bahwa semakin kecil nilai gap, maka organisasi semakin siap/baik/optimal dalam penerapan standar.
Dari 7 (tujuh) aspek yang dinilai, diketahui bahwa seluruh aspek sudah dalam tahap level optimal. Pada aspek kepemimpinan, menunjukkan sebagai unsur yang telah berhasil melaksanakan dan wajib dipertahankan. Sedangkan pada aspek lainnya hampir keseluruhan menunjukkan sebagai atribut yang telah mempengaruhi impelementasi SMAP dan termasuk sebagai faktor determinan yang dianggap sangat penting namun implementasinya belum sesuai sehingga kurang memenuhi standar. Oleh karena itu unit analisis layak untuk mempertahankan dan berkewajiban secara terus menerus dan berkelanjutan untuk meningkatkan kualitas pelayanan publik terkait penerapan sistem manajemen anti penyuapan ini di dalam organisasinya.

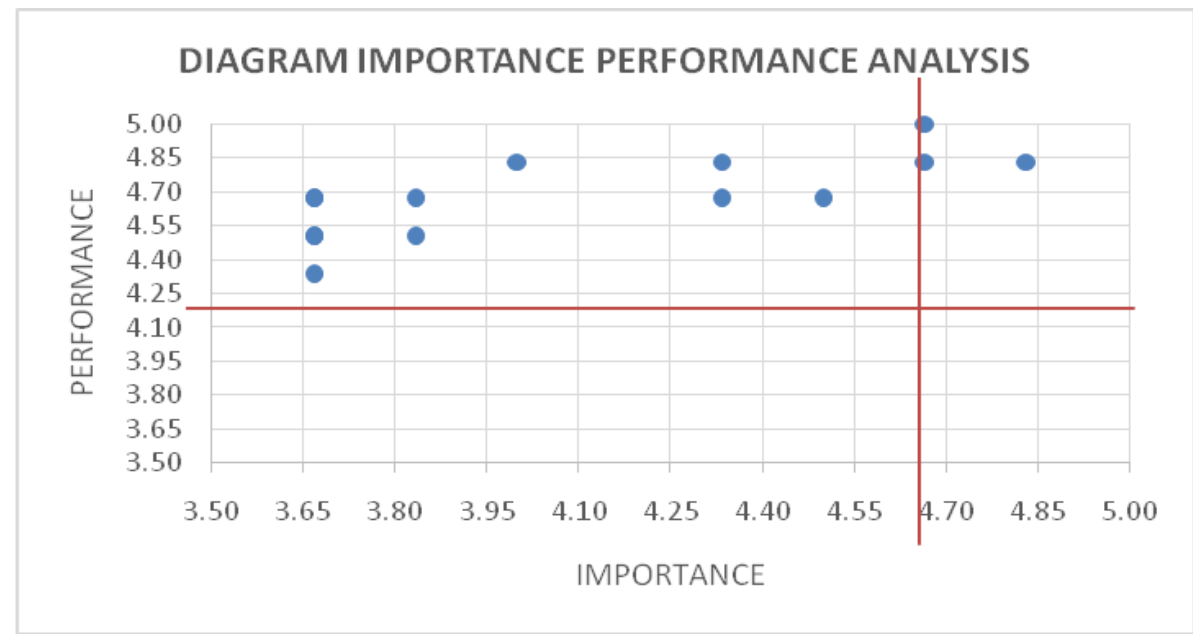

Gambar 3 Importance-Performance Analysis tingkat implementasi SMAP ISO 37001.

\section{KESIMPULAN}

Berdasarkan hasil penilaian pada unit analisis dapat disimpulkan bawa tingkat efektifitas pelaksanaan (kondisi pada saat penilaian) pada tujuh aspek sesuai standar mempunyai nilai rata-rata 4,10 atau berada pada level optimal, sedangkan pada tingkat kepentingan diimplementasikannya standar menurut persepsi para responden mempunyai nilai rerata 4,68 atau dianggap sangat penting. Nilai kesenjangan sebesar 0,42 (sangat kecil). Unit analisis sudah mampu memahami dan memiliki kemampuan untuk beradaptasi dan fleksibel terhadap persyaratan yang ditentukan dalam SMAP. Meskipun penilaian optimal yang diperoleh tidak membuat unit analisis untuk meninggalkan sistem MAP yang berjalan karena core business pelayanan pendidikan dan pelatihan serta kajian publik yang diberikan.

Rekomendasi yang diberikan adalah; Pertama, mempertahankan aspek kepemimpinan sebagai faktor determinan keberhasilan implementasi SMAP.Kedua,meningkatkan kualitas implementasi dan melakukan evaluasi atas implementasi pada aspek lainnya yaitu organisasi, operasi, dan peningkatan khususnya pada aspek perencanaan, dukungan, dan tinjauan manajemen.

\section{UCAPAN TERIMA KASIH}

Pertama-tama, terima kasih kepada ALLAH S.W.T atas belas kasih dan bimbingannya dalam memberikan kami kekuatan penuh untuk 
menyelesaikan riset ini. Terima kasih banyak kepada organisasi tempat kami bernaung, Lembaga Administrasi Negara, dan keluarga dan rekan sejawat kami dalam dukungan materil immaterial.

Terima kasih atas mitra penelitian yang telah berkontribusi dalam studi ini, responden survey yang merupakan perwakilan manajemen objek penelitian diantaranya Bapak Mariman Darto sebagai Kepala Pusat. Bapak Muhammad Aristian selaku perwakilan Worlwide Quality Assurance (WQA), badan sertifikasi manajemen, yang telah berkontribusi dalam data dan informasi terkait SMAP, dan seluruh partisipan dalam proyek riset ini.

\section{DAFTAR PUSTAKA}

Anggraeni, T. D. (2014). Menciptakan Sistem Pelayanan Publik yang Baik: Strategi Reformasi Birokrasi dalam Pemberantasan Korupsi. Rechts Vinding, 3(3), 417-433. Retrieved from ejournal.radenintan.ac.id/.

Boly, A., \& Gillanders, R. (2018). Anti-corruption policy making, discretionary power and institutional quality: An experimental analysis. Journal of Economic Behavior and Organization, 152, 314-327. https://doi.org/10.1016/j.jebo.2018.05.007

Cragg, W. (2016). Bribery, Corruption and Moral Norms Across National Boundaries A work in progress for the Routledge Companion to Business Ethics. (April). https://doi.org/10.13140/RG.2.1.4729.944 8

Hanum, Z., \& Syahr, A. (2019). Evaluation the Implementation of Court Quality Accreditation Standard Using. 115-124.

Indonesia, S. N., \& Nasional, B. S. (2016). Sistem manajemen anti penyuapan Persyaratan dengan panduan penggunaan Anti-bribery management systems - Requirements with.

Joseph Joseph, C., Gunawan, J., Sawani, Y., Rahmat, M., Avelind Noyem, J., \& Darus, F. (2016). A comparative study of anticorruption practice disclosure among Malaysian and Indonesian Corporate Social Responsibility (CSR) best practice companies. Journal of Cleaner Production, 112, 2896-2906. https://doi.org/10.1016/j.jclepro.2015.10.0 91
Kafel, P. (2016). Anti-Bribery Management System As a Tool To Increase Quality of life. 1st International Conference on Quality of Life, (June), 221-224.

Kapeli, N. S., \& Mohamed, N. (2015). Insight of Anti-Corruption Initiatives in Malaysia. Procedia Economics and Finance, 31(15), 525-534. https://doi.org/10.1016/s22125671(15)01197-1

Lombardi, R., Trequattrini, R., Cuozzo, B., \& Cano-Rubio, M. (2019). Corporate corruption prevention, sustainable governance and legislation: First exploratory evidence from the Italian scenario. Journal of Cleaner Production, 217 , 666-675. https://doi.org/10.1016/j.jclepro.2019.01.2 14

Lukiawan, R. (2019). Kesiapan Organisasi Dalam Implementasi Standar Iso 37001 (Studi Kasus Di Ud. X Dan Dinas Y). Jurnal Standardisasi, 20(2), 159. https://doi.org/10.31153/js.v20i2.713

Pavroz, A. (2017). Corruption-oriented model of governance in contemporary Russia. Communist and Post-Communist Studies, 50(2), 145-155. https://doi.org/10.1016/j.postcomstud.201 7.05.005

Prof. Dr. H. Mudjia Rahardjo, M. S. (2017). Studi Pustaka dalam Penelitian Kualitatif: Konsep dan Prosedurnya. UIN Maulana Malik Ibrahim Malang Program Pascasarjana. Retrieved from http://scholar.google.co.id/citations?user= E-DA_7EAAAAJ\&hl=id

Sihombing, S. O. (2018). Youth perceptions toward corruption and integrity: Indonesian context. Kasetsart Journal of Social Sciences, 39(2), 299-304. https://doi.org/10.1016/j.kjss.2018.03.004

WQA. (2019). Apa itu ISO 37001. Retrieved May 20, 2019, from wqa.co.id website: https://wqa.co.id/apa-itu-iso-37001/

Zhang, H., Song, Y., Tan, S., Xia, S., Zhang, H., Jiang, C., ... Lv, Y. (2019). Anti-corruption efforts, public perception of corruption, and government credibility in the field of real estate: An empirical analysis based on twelve provinces in China. Cities, 90(December 2018), 64-73. https://doi.org/10.1016/j.cities.2019.01.04 2 